\title{
LIFE AND DEATH
}

oF

WILLIAM BEDELL. 


\section{A TRUE RELATION OF \\ THE LIFE AND DEATH \\ oF \\ THE RIGHT REVEREND FATHER IN GOD \\ W ILLIA M BEDLL, \\ LORD BISHOP OF KILMORE IN IRELAND.}

EDITED FROM A MS. IN THE BODLEIAN LIBRARY, OXFORD, AND AMPLIFIED WITH GENEALOGICAI. AND HISTORICAL CHATTERS, COMPILED FROM ORIGINAL SOURCES,

BY

THE REPRESENTATIVE OF THE BISHOP'S MOTHER'S FAMILY OF ELLISTON,

THOMAS WHARTON JONES, F.R.S.

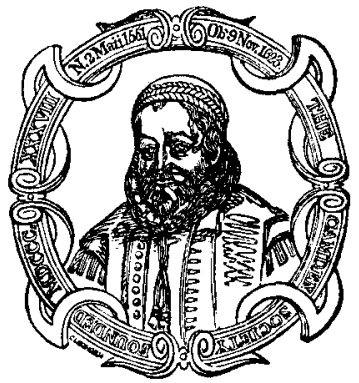

PRINTED FOR THE CAMDEN SOCIETY.

M.DCCC.LXXII. 
WESTMINSTER:

PRINTED BY J. B. NICHOLS AND SONS,

25, PARLIAMENT STREET.

[NEW SERIES, IV.] 


\section{COUNCIL OF THE CAMDEN SOCIETY}

FOR THE YEAR 1871-72.

\section{President,}

SIR WILLIAM TITE, C.B., M.P., F.R.S., V.P.S.A.

WILLIAM CHAPPELL, ESQ. F.S.A, Treasurer.

WILLIAM DURRANT COOPER, ESQ. F.S.A.

F. W. COSENS, ESQ.

JOHN FORSTER, ESQ. D.C.L.

SAMUEL RAWSON GARDINER, ESQ.

ALFRED KINGSTON, ESQ.

SIR JOHN MACLEAN, F.S.A.

SIR FREDERIC MADDEN, F.R.S.

FREDERIC OUVRY, ESQ. Treas. S.A.

EDWARD RIMBAULT, LL.D.

EVELYN PHILIP SHIRLEY, ESQ. M.A. F.S.A.

WILLIAM JOHN THOMS, ESQ. F.S.A., Secretary.

THE VERY REV. THE DEAN OF WESTMINSTER, F.S.A

SIR THOMAS E. WINNINGTON, BART.

SIR ALBERT W. WOODS, Garter, F.S.A. 
The Council of the Camden Societr desire it to be understood that they are not answerable for any opinions or observations that may appear in the Society's publications; the Editors of the several Works being alone responsible for the same. 